\title{
Toilet Training and Less Fiber Consumption as Risk Factors of Constipation in Preschool Children
}

\begin{abstract}
CrossMark
\end{abstract}
I Made Suwanantaa, Ni Nyoman Metriani Nesab ${ }^{b}$, Putu Gede Karyanac, I Gusti Ngurah Sanjaya Putrad

Manuscript submitted: 09 September 2020, Manuscript revised: 27 October 2020, Accepted for publication: 18 November 2020

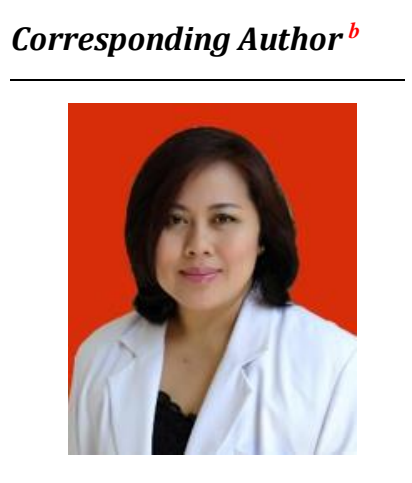

Keywords

children;

constipation;

fiber;

risk factor;

toilet training;

\begin{abstract}
This study aimed to determine the prevalence and risk factors for children with constipation. This research was an analytic cross-sectional study. The sampling method was cluster sampling. The research was conducted at some kindergartens in Denpasar, Bali from October to November 2019. Data were obtained based on questionnaires distributed to parents and anthropometric examinations. Constipation was defined according to The Rome IV criteria. There were 215 children included in the study and 43 (20\%) children had constipation. Children who started toilet training before the age of 1.5 years or after 2 years had 2,73 times the risk of developing constipation ( $p=0.019 ; 95 \%$ CI 1.18-6.3). Children with less fiber consumption in a day had the risk of experiencing constipation 7.25 times ( $p=0.001 ; 95 \%$ CI 3.38-15.5). Other risk factors such as sex, physical activity, screen contact, water consumption, nutritional status, birth weight, and mother education did not statistically relate to constipation. Toilet training before the age of 1.5 years or after 2 years and low fiber consumption are risk factors for constipation in preschool children in Denpasar.
\end{abstract}

\section{Contents}

Abstract

1 Introduction.

2 Materials and Methods.

3 Results and Discussions...

4 Conclusion

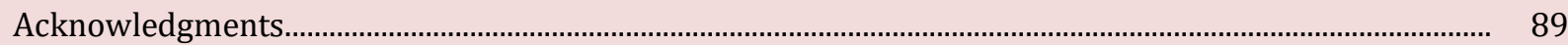

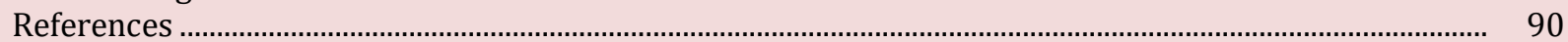

a Department of Child Health, Medical School of Udayana University, Denpasar, Indonesia

b Department of Child Health, Medical School of Udayana University, Denpasar, Indonesia

c Department of Child Health, Medical School of Udayana University, Denpasar, Indonesia

d Department of Child Health, Medical School of Udayana University, Denpasar, Indonesia 


\section{Introduction}

Constipation is difficulty in defecating or decreasing the frequency of bowel movement. According to Rome IV criteria, the diagnosis of constipation is confirmed if there are 2 or more of the following symptoms: frequency of two or fewer bowel movements a week, at least 1 episode of encopresis per week, history of posture withholding bowel movement, history of stool that is harder than usual or painful, is present. Large stool mass in the rectum, the size of large stool that fills the toilet. These symptoms last at least once a week for at least a month (Heron et al., 2018).

Constipation is one of the gastrointestinal problems that often occur and not only affects the quality of life of children with constipation but also caregivers and their families (Wang et al., 2013; Aryani et al., 2017). Apart from being a health problem, constipation also carries a high financing burden (Walter et al., 2019). Three percent of patient visits to pediatricians and $10-15 \%$ of cases handled by consultant gastrohepatologist pediatricians are constipation (Juffrie et al., 2010). Several studies state that the prevalence of constipation ranges from 3-30\% (Heron et al., 2018; Olaru et al., 2016; Haghighat et al., 2018; Kranz et al., 2012) Most cases or $90-95 \%$ are functional constipation while $5-10 \%$ are caused by organic disorders (Juffrie et al., 2010). Constipation is not only a problem in Indonesia but various countries in the world, therefore constipation is a global health problem (Levy et al., 2017; Fishman et al., 2004; Talley et al., 2003). The incidence of constipation is proportional to men and women. The ratio of male to female constipation is 1: 1.01, while the mean age of children with constipation is 4.8 years (Haghighat et al., 2018).

Several factors that influence the occurrence of constipation include the volume of water consumed in a day, physical activity, and the length of screen time in a day, the time to start toilet training, and nutritional status (Walter et al., 2019; Olaru et al., 2016). Research conducted by Yang et al found that consumption of fiber-rich foods helps increase the frequency of bowel movement and reduces the risk of constipation (Yang et al., 2012). Research by Huang et al found that lack of physical activity is a risk of constipation (Huang et al., 2014). Another study by Park et al found that water consumption of fewer than $500 \mathrm{ml}$ per day is associated with constipation in children (Park et al., 2016; Rutter, 2000; Stuckyropp \& DiLorenzo, 1993).

Given the magnitude of the impact of constipation on the quality of life of children, it is important to define the prevalence and risk factors that influence it so that interventions can be carried out. Several studies have been conducted to determine the prevalence and risk factors for constipation in children, but until the present, a lack of research has been conducted in Indonesia, especially in Bali. Therefore, this research was conducted in preschool in Bali to determine the prevalence and risk factors for children with constipation.

\section{Materials and Methods}

This study was an analytical study with a cross-sectional design to determine the prevalence and risk factors for constipation in preschool children in Denpasar. The sampling method was cluster sampling and the research subject data was obtained from the results of questionnaires distributed to all students and anthropometric examinations conducted at preschool Melati, Lokasari, Dwi Tunggal, Tadika Putri, Bhakti Mulia, Shantika Kumara, Angsa, Widya Mutiara, Sari Dewi, Kusuma, Kerti Budaya, Harapan Mulia, Kasih Sayang, Widya Mekar, Kumara Jaya, and Indraprasta in the Denpasar area, Bali from October to November 2019.

The target population was children with constipation. The affordable population ware children with constipation in early childhood schools in Denpasar. The sample population was a population that meets the inclusion and exclusion criteria. The inclusion criteria were all preschool children aged 3-5 years in the preschool school in Denpasar. The exclusion criteria were parents who refused to participate in the study or questionnaire data were incomplete. Figure 1 shows the research flow. 


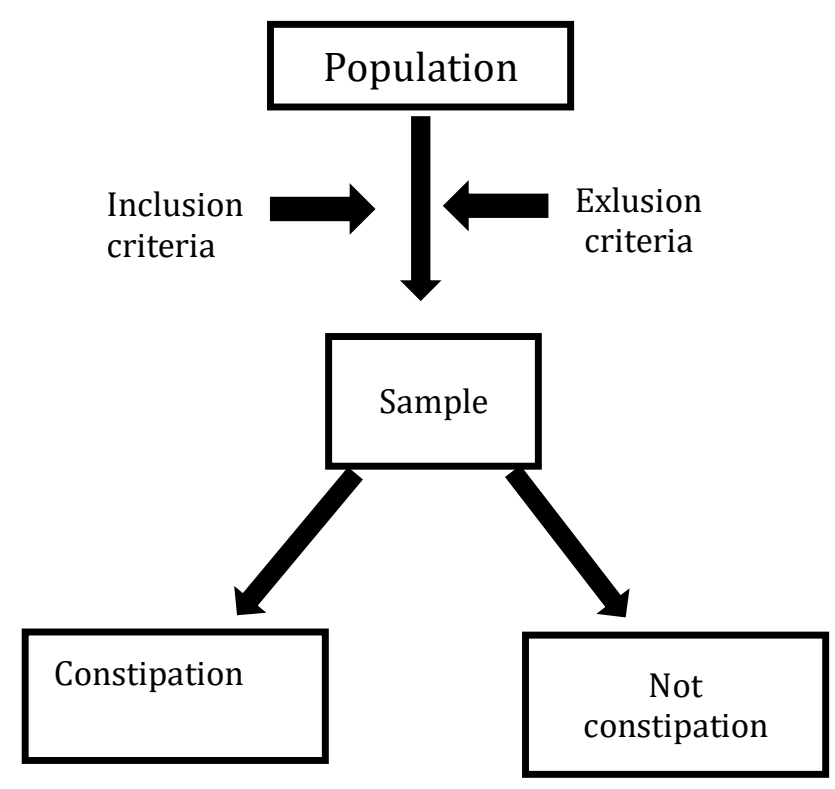

Figure 1. Scheme of study

Data collected by questionnaire included age, sex, constipation, age at the commencement of toilet training, duration of physical activity in 24 hours, adequacy of fiber, duration of screen contact in 24 hours, the volume of water consumed in 24 hours, birth weight, and maternal education. Data for nutritional status was obtained from anthropometric measurements. After the data was collected, the sample will be divided into 2 groups, constipation, and non-constipation. The outcome of this study was the prevalence and risk factors of constipation.

The sample size was determined by the unpaired comparative categoric sample formula with type I error of $5 \%$, type II error of $20 \%$, and the highest proportion of constipation based on the literature is $30 \%$. After all, data has been collected, the analysis was carried out with a computer program. Odds ratios were calculated and the chi-square test was used to determine the difference in the association between risk factors and constipation. The influence of external variables and dependent variables was then analyzed by logistic regression. The statistical test was considered significant if the p-value $<0.05$.

Constipation was defined as 2 or more of the following symptoms: decreased frequency of 2 or fewer bowel movements a week or at least 1 episode of encopresis (tsp) per week, or a history of posture withholding bowel movement, or a history of stool that is harder than usual or painful, or a stool mass large ones in the rectum, or large stools that fill the toilet. These symptoms last at least once a week for at least a month (Heron et al., 2018). This variable is divided into (1) constipation, and (2) no constipation. Age was obtained from the difference between the date of examination when being sampled and the date of birth, expressed in years with rounding down if less than 15 days and rounding up if more or equal to 15 days. Data was presented on a numeric scale with units of years. Gender was determined based on the appearance of the phenotype, divided into two categories, namely (1) male and (2) female. Physical activities were physical activities carried out by children such as playing, walking, or running. Physical activity was presented in categories, namely (1) activity 2 hours or more, and (2) activity less than 2 hours. Screen time was the time spent using electronic devices such as television, gadged, computers, and cellphones. This category is divided into (1) more than 2 hours and (2) a maximum of 2 hours a day. Fiber diet is the amount of fiber consumed in a day and can be divided into (1) adequate fiber if consumed according to daily needs according to age and (2) lack of fiber if subject consumed less fiber than daily needs according to age (Schnoll \& Zimmerman, 2001; Slavin, 2005). Water consumption was the volume of water that is drunk in 24 hours. This variable was divided into (1) drinking $500 \mathrm{ml}$ or more in 24 hours and (2) less than $500 \mathrm{ml}$ in 24 hours. Nutritional status in children was determined from measurements of height and weight. Classified as (1) overweight or obese when the Waterlow was $>110 \%$ and not overweight or obese if the maximum water flow is $110 \%$. Toilet

Suwananta, I. M. ., Nesa, N. N. M. ., Karyana, I. P. G. ., \& Putra, I. G. N. S. . (2020). Toilet training and less fiber consumption as risk factors of constipation in preschool children. International Journal of Health Sciences, 4(3), 83-92. https://doi.org/10.29332/ijhs.v4n3.474 
training was a child's exercise for bowel movement and urination (Barone et al., 2009; Cicero \& Pfadt, 2002). The age at the commencement of toilet training was divided into (1) ages less than 1.5 or more than 2 years old and (2) ages 1.5-2 years. Birth weight is the weight measured at birth. Divided into (1) low birth weight (LBW) if the birth weight $<2500$ and (2) not LBW if the birth weight $\geq 2500$ grams. Maternal education was divided into (1) higher education if the parent has passed a diploma or bachelor's degree and (2) not higher education if the parent did not attend a school or have a maximum education up to high school.

\section{Results and Discussions}

Data were collected from October to November 2019 at preschool Melati, Lokasari, Dwi Tunggal, Tadika Putri, Bhakti Mulia, Shantika Kumara, Angsa, Widya Mutiara, Sari Dewi, Kusuma, Kerti Budaya, Harapan Mulia, Kasih Sayang, Widya Mekar, Kumara Jaya, and Indraprasta, Denpasar city. Of the 215 children who met the inclusion and exclusion criteria, it was found that $43(20 \%)$ children experienced constipation. The sample ages ranged from 3-6 years with a mean of 5 years. Women get a little more than men. Toilet training that starts before the age of 1.5 years and after 2 years is more than between the ages of $1.5-2$ years. Physical activity $<2$ hours is more than 2 hours or more a day. Samples with less fiber are more numerous than sufficient fiber. The complete characteristic data are described in table 1.

Table 1

Sample Characteristic

\begin{tabular}{ll}
\hline Variable & $\mathrm{n}=215$ \\
Age, median (range) & $5(3-6)$ \\
\hline Sex, n (\%) & $106(49,3)$ \\
Male & $109(50,7)$ \\
Female & $122(56,7)$ \\
\hline Toilet training, $\mathrm{n}(\%)$ & $93(43,3)$ \\
$<1,5$ years or $>2$ years & \\
1,5-2 years & $204(94,9)$ \\
\hline Physical activity, $\mathrm{n}(\%)$ & $11(5,1)$ \\
$<2$ hours & \\
2 hours or more & $51(23,7)$ \\
\hline Fiber, $\mathrm{n}(\%)$ & $164(76,3)$ \\
Low fiber & \\
Enough fiber & $84(39,1)$ \\
\hline Screen contact, $\mathrm{n}(\%)$ & $131(60,9)$ \\
$>2$ hours & \\
Maximum 2 hours & $14(6,5)$ \\
\hline Water consumption, $\mathrm{n}(\%)$ & $201(93,5)$ \\
$\leq 500$ ml/day & \\
$>500$ ml/day & $55(25,6)$ \\
\hline Nutritional status, $\mathrm{n}(\%)$ & $160(74,7)$ \\
Overweight or obesitas & $16(7,4)$ \\
Not Overweight or obesitas & $199(92,6)$ \\
\hline Birth weight, $\mathrm{n}(\%)$ & $118(54,9)$ \\
Low birth weight & $97(45,1)$ \\
Not Low birth weight & \\
\hline Mother education, $\mathrm{n}(\%)$ & \\
Low education & \\
High education & \\
\hline
\end{tabular}


Based on bivariate analysis, we found toilet training before the age of 1.5 years or after 2 years of age, water consumption $\leq 500 \mathrm{ml} /$ day, and lack of fiber were significant risk factors for constipation. We also performed multivariate analysis and found toilet training before the age of 1.5 years or after 2 years of age and lack of fiber were significantly correlated.

Table 2

Bivariat analysis risk factor of constipation

\begin{tabular}{|c|c|c|c|c|c|}
\hline Risk factor & $\begin{array}{c}\text { Constipation } \\
\mathrm{N}\end{array}$ & $\begin{array}{c}\text { Not } \\
\text { constipation } \\
\text { n } \\
\end{array}$ & $\begin{array}{c}\mathrm{p} \\
\text { value }\end{array}$ & $\begin{array}{l}\text { Prevalence } \\
\text { ratio }\end{array}$ & $\begin{array}{l}\text { Confidence } \\
\text { Interval } \\
95 \%\end{array}$ \\
\hline $\begin{array}{l}\text { Sex, n (\%) } \\
\text { Male } \\
\text { Female }\end{array}$ & $\begin{array}{l}16 \\
27\end{array}$ & $\begin{array}{l}90 \\
82\end{array}$ & 0,76 & 0,54 & $0,27-1,07$ \\
\hline $\begin{array}{l}\text { Toilet training, } \mathrm{n}(\%) \\
<1,5 \text { years or }>2 \text { years } \\
1,5-2 \text { years }\end{array}$ & $\begin{array}{l}33 \\
10\end{array}$ & $\begin{array}{l}89 \\
83\end{array}$ & 0,003 & 3,0 & $1,42-6,63$ \\
\hline $\begin{array}{l}\text { Physical activity, } \mathrm{n}(\%) \\
<2 \text { hours } \\
2 \text { hours or more }\end{array}$ & $\begin{array}{c}4 \\
39 \\
\end{array}$ & $\begin{array}{c}7 \\
165 \\
\end{array}$ & 0,23 & 2,4 & $0.67-8,67$ \\
\hline $\begin{array}{l}\text { Fiber, } \mathrm{n}(\%) \\
\text { Low fiber } \\
\text { Enough fiber }\end{array}$ & $\begin{array}{l}25 \\
18 \\
\end{array}$ & $\begin{array}{c}26 \\
146 \\
\end{array}$ & 0,001 & 7,79 & $3,73-16,27$ \\
\hline $\begin{array}{l}\text { Screen contact, } n(\%) \\
>2 \text { hours } \\
\text { Maximum } 2 \text { hours }\end{array}$ & $\begin{array}{l}21 \\
22 \\
\end{array}$ & $\begin{array}{c}63 \\
109 \\
\end{array}$ & 0,142 & 1,6 & $0,84-3,23$ \\
\hline $\begin{array}{l}\text { Water consumption, } \mathrm{n} \\
(\%) \\
\leq 500 \mathrm{ml} / \text { day } \\
>500 \mathrm{ml} / \text { day }\end{array}$ & $\begin{array}{c}7 \\
36\end{array}$ & $\begin{array}{c}7 \\
165\end{array}$ & 0,009 & 4,5 & $1,51-13,8$ \\
\hline $\begin{array}{l}\text { Nutritional } \\
\text { status, n (\%) } \\
\text { Overweight or obesity } \\
\text { Not Overweight or } \\
\text { obesity }\end{array}$ & $\begin{array}{l}15 \\
28\end{array}$ & $\begin{array}{c}40 \\
132\end{array}$ & 0,11 & 1,76 & $0,86-3,63$ \\
\hline $\begin{array}{l}\text { Birth weight, } \mathrm{n}(\%) \\
\text { Low birth weight } \\
\text { Not Low birth weight }\end{array}$ & $\begin{array}{c}4 \\
39 \\
\end{array}$ & $\begin{array}{c}12 \\
160 \\
\end{array}$ & 0.63 & 1.36 & $0.41-4.47$ \\
\hline $\begin{array}{l}\text { Mother } \\
\text { education, n (\%) } \\
\text { Low education } \\
\text { High education }\end{array}$ & $\begin{array}{l}25 \\
18\end{array}$ & $\begin{array}{l}93 \\
79\end{array}$ & 0.63 & 118 & $0.6-2.3$ \\
\hline
\end{tabular}

Tabel 3

Multivariat Analysis risk factor of constipation

\begin{tabular}{lccc}
\hline \multicolumn{1}{c}{ Risk Factor } & p-value & $\begin{array}{c}\text { Prevalence } \\
\text { ratio }\end{array}$ & Confidence Interval 95\% \\
\hline $\begin{array}{l}\text { Toilet training } \\
<1,5 \text { years or }>2 \text { years } \\
1,5-2 \text { years }\end{array}$ & 0,019 & 2,73 & $1,18-6,3$ \\
\hline
\end{tabular}

Suwananta, I. M. ., Nesa, N. N. M. ., Karyana, I. P. G. ., \& Putra, I. G. N. S. . (2020). Toilet training and less fiber consumption as risk factors of constipation in preschool children. International Journal of Health Sciences, 4(3), 83-92. https://doi.org/10.29332/ijhs.v4n3.474 


\begin{tabular}{lccc}
\hline $\begin{array}{l}\text { Fiber } \\
\text { Low fiber } \\
\text { Enough fiber }\end{array}$ & 0,001 & 7,25 & $3,38-15,5$ \\
\hline $\begin{array}{l}\text { Water consumption } \\
\leq 500 \mathrm{ml} / \text { day }\end{array}$ & 0,052 & 3,3 & $0,99-11,5$ \\
$>500 \mathrm{ml}$ day & & & \\
\hline
\end{tabular}

\section{Discussion}

In this study, it was found that the prevalence of constipation in PAUD children was 20\%. These results are following the prevalence of constipation in the pediatric population, which ranges from $3-30 \%$ (Olaru et al., 2016; Heron et al., 2018; Haghighat et al., 2018; Kranz et al., 2012). A total of 106 men (49.3\%) and 109 $(50.7 \%)$ women participated in this study and there was no statistical difference in the incidence of constipation between men and women. This result was similar to a study conducted by Olaru et al. (2016), where there was no significant difference in the incidence of constipation between men and women. At first, constipation was thought to be influenced by hormonal factors, but this did not occur between the ages of 3-5 years (Walter et al., 2019).

In this study, there was no significant difference in the incidence of constipation in the group of children who did the physical activity for 2 hours or more than for less than 2 hours. Physical activity can increase intestinal drainage by increasing the movement of food towards the colon. This movement together with gravity will push the contents of the colon towards the rectum and stimulate bowel movement (Haghighat et al., 2018). But on the other hand, physical exercise did not have a good effect on constipation because during exercise there is an obstacle to gastrointestinal function due to the concentration of blood flow to the muscles and skin (Haghighat et al., 2018).

The American Academy of Pediatrics recommends a maximum screen time of 2 hours a day (Chassiakos et al., 2016). Screen time over a longer period was associated with a reduced duration of physical activity. In this study, there was no significant difference between constipation in the group with a maximum screen time of 2 hours/day compared to more than 2 hours because the screen time duration was related to the duration of physical activity and in this study also did not find a significant relationship between constipation and the duration of physical activity.

Children with water consumption of $\leq 500 \mathrm{ml} /$ day have a 4.5 times risk of experiencing constipation. The results were following research conducted by Park et al., 2016 which states that water consumption was less at risk of constipation because it was useful for maintaining stool consistency so that it is not so hard (Park et al., 2016). In this study, after multivariate analysis, we didn't find a significant association. It could be caused by an inappropriate estimation of water volume that should be done based on water daily need per kg in 24 hours.

Fiber causes mechanical stimulation and osmosis which is necessary for colonic stimulation. Fiber also increases gas production and floor bacteria which increase colonic stimulation (Haghighat et al., 2018). The results of this study found that the risk of constipation was 7.7 times in the group with less fiber than enough fiber with a p-value $<0.005$. These results were consistent with research conducted by Castilejjo et al., (2006). The group who received fiber supplements compared to placebo experienced an improvement in constipation symptoms. This occurs because the fibers increased movement in the colon and reduce transit time in the colon (Castillejo et al., 2006).

In this study, we found that children who started toilet training before the age of 1.5 years or after 2 years of age had a 3.6 times risk of constipation compared to those who started between the ages of 1.5-2 years. This result was following the research of Heron et al., 2018 which stated that children who start toilet training before the age of 6 months compared to 6-15 months are at risk of experiencing constipation. Other studies suggest that toilet training should be done at the age of 1.5-2 years because, at this age range, the abilities needed for toilet training already exist in most children, including the ability to control urination and sphincter ani. In observations made on $41 \%$ of mothers who gave toilet training before the age of 18 months, the child had not been able to defecate properly and was still wearing a diaper (Mota \& Barros, 2008). In 
another study conducted by Olaru et al. (2016), also stated that there was a relationship between the incidence of constipation and the age at which toilet training was started (Olaru et al., 2016).

The relationship between constipation and being overweight or obese is still controversial. A study conducted by Olaru et al. (2016), found a relationship between overweight or obesity and the incidence of constipation in children. This is because obesity is associated with the consumption of high-calorie foods such as fast food and soft drinks and the consumption of low-fiber foods. Obesity is also thought to cause intestinal motility disorders. This was different from this study where there was no significant relationship between overweight and obesity with constipation. This is because obesity and overweight are more related to physical activity, while physical activity has no significant relationship with constipation (Olaru et al., 2016).

In this study, there was no significant relationship between birth weight and risk of constipation because there were no comorbidities such as neurological disorders or necrotizing enterocolitis (NEC). One study suggests that constipation in low birth weight infants is associated with neurological developmental disorders and may also be a secondary consequence of neonatal ischemic conditions such as necrotizing enterocolitis (Cunningham et al., 1998). Research by Shan-Ming Chen, et al also stated that constipation is associated with NEC (Chen et al., 2020).

In this study, there was no statistically significant relationship between maternal education level and constipation in children. It was following the research of Walter et al. (2019). Other studies suggest that constipation was associated with children's quality of life scores. The child's quality of life score was related to several other factors such as the relationship with family, family economic status, education level of caregivers or parents, and duration of constipation. In this study, there was no relationship between maternal education level and constipation because the level of education was related to the quality of life score which was also influenced by other factors. The drawback of this study was that there was no assessment of the child's life quality score (Wang et al., 2013).

\section{Conclusion}

The prevalence of constipation in preschool children in Denpasar was 20\%. Risk factors associated with constipation were timing to start toilet training before 1.5 years or after 2 years and low fiber consumption.

\section{Limitation of this study}

The weakness of this study was that it uses data based on reports and parental memories so that it could cause bias. This study also has not been able to distinguish functional constipation from organic causes.

\section{Acknowledgments}

We are grateful to two anonymous reviewers for their valuable comments on the earlier version of this paper.

Suwananta, I. M. ., Nesa, N. N. M. ., Karyana, I. P. G. ., \& Putra, I. G. N. S. . (2020). Toilet training and less fiber consumption as risk factors of constipation in preschool children. International Journal of Health Sciences, 4(3), 83-92. https://doi.org/10.29332/ijhs.v4n3.474 


\section{References}

Aryani, L. N. A., Ardjana, I. E., \& Hanati, N. (2017). Emotion and behaviour disorders towards children of maternal depression in psychiatry polyclinic at RSUP Sanglah. International research journal of engineering, IT \& scientific research, 3(2), 139-149.

Barone, J. G., Jasutkar, N., \& Schneider, D. (2009). Later toilet training is associated with urge incontinence in children. Journal of Pediatric Urology, 5(6), 458-461. https://doi.org/10.1016/j.jpurol.2009.05.012

Castillejo, G., Bulló, M., Anguera, A., Escribano, J., \& Salas-Salvadó, J. (2006). A controlled, randomized, doubleblind trial to evaluate the effect of a supplement of cocoa husk that is rich in dietary fiber on colonic transit in constipated pediatric patients. Pediatrics, 118(3), e641-e648.

Chassiakos, Y. L. R., Radesky, J., Christakis, D., Moreno, M. A., \& Cross, C. (2016). Children and adolescents and digital media. Pediatrics, 138(5), e20162593.

Chen, S. M., Huang, J. Y., Wu, M. C., \& Chen, J. Y. (2020). The Risk of Developing Constipation After Neonatal Necrotizing Enterocolitis. Frontiers in Pediatrics, 8, 120.

Cicero, F. R., \& Pfadt, A. (2002). Investigation of a reinforcement-based toilet training procedure for children with autism. Research in Developmental Disabilities, 23(5), 319-331. https://doi.org/10.1016/S08914222(02)00136-1

Cunningham, C., Taylor, H. G., Klein, N., Minich, N. M., \& Hack, M. (1998). Constipation is a Problem Among Former< 750 Gram Birthweight (ELBW) Children. 569. Pediatric Research, 43(4), 100-100.

Fishman, L., Lenders, C., Fortunato, C., Noonan, C., \& Nurko, S. (2004). Increased prevalence of constipation and fecal soiling in a population of obese children. The Journal of pediatrics, 145(2), 253-254. https://doi.org/10.1016/j.jpeds.2004.04.022

Haghighat, M., Amiri, Z., Dehghani, S. M., Safarpour, A. R., Ataollahi, M., Mani, A., ... \& Rezaianzadeh, A. (2018). Investigation of demographic and clinical characteristics of children with constipation referring to the pediatric gastrointestinal clinic, Shiraz in 2014-2016. Shiraz E-Medical Journal, 19(2).

Heron, J., Grzeda, M., Tappin, D., von Gontard, A., \& Joinson, C. (2018). Early childhood risk factors for constipation and soiling at school age: an observational cohort study. BMJ paediatrics open, 2(1).

Huang, R., Ho, S. Y., Lo, W. S., \& Lam, T. H. (2014). Physical activity and constipation in Hong Kong adolescents. Plos one, 9(2), e90193.

Juffrie, M., Soenarto, S. S., Oswari, H., Arief, S., Rosalina, I., \& Mulyani, N. S. (2010). Buku Ajar GastroenterologiHepatologi Jilid 1. Jakarta: Balai Penerbit IDAI.

Kranz, S., Brauchla, M., Slavin, J. L., \& Miller, K. B. (2012). What do we know about dietary fiber intake in children and health? The effects of fiber intake on constipation, obesity, and diabetes in children. Advances in nutrition, 3(1), 47-53.

Levy, E. I., Lemmens, R., Vandenplas, Y., \& Devreker, T. (2017). Functional constipation in children: challenges and solutions. Pediatric health, medicine and therapeutics, 8, 19.

Mota, D. M., \& Barros, A. J. (2008). Toilet training: situation at 2 years of age in a birth cohort. Jornal de Pediatria, 84(5), 455-462.

Olaru, C., Diaconescu, S., Trandafir, L., Gimiga, N., Stefanescu, G., Ciubotariu, G., \& Burlea, M. (2016). Some risk factors of chronic functional constipation identified in a pediatric population sample from Romania. Gastroenterology research and practice, 2016.

Park, M., Bang, Y. G., \& Cho, K. Y. (2016). Risk factors for functional constipation in young children attending daycare centers. Journal of Korean medical science, 31(8), 1262-1265.

Rutter, M. (2000). Children in substitute care: Some conceptual considerations and research implications. Children and youth services review, 22(9-10), 685-703. https://doi.org/10.1016/S01907409(00)00116-X

Schnoll, R., \& Zimmerman, B. J. (2001). Self-regulation training enhances dietary self-efficacy and dietary fiber consumption. Journal of the American Dietetic Association, 101(9), 1006-1011. https://doi.org/10.1016/S0002-8223(01)00249-8

Slavin, J. L. (2005). Dietary fiber and body weight. Nutrition, 21(3), 411-418. https://doi.org/10.1016/j.nut.2004.08.018

Stuckyropp, R. C., \& DiLorenzo, T. M. (1993). Determinants of exercise in children. Preventive medicine, 22(6), 880-889. https://doi.org/10.1006/pmed.1993.1079 
Talley, N. J., Jones, M., Nuyts, G., \& Dubois, D. (2003). Risk factors for chronic constipation based on a general practice sample. The American journal of gastroenterology, 98(5), 1107-1111. https://doi.org/10.1016/S0002-9270(03)00239-9

Walter, A. W., Hovenkamp, A., Devanarayana, N. M., Solanga, R., Rajindrajith, S., \& Benninga, M. A. (2019). Functional constipation in infancy and early childhood: epidemiology, risk factors, and healthcare consultation. BMC pediatrics, 19(1), 285.

Wang, C., Shang, L., Zhang, Y., Tian, J., Wang, B., Yang, X., ... \& Xu, Y. (2013). Impact of functional constipation on health-related quality of life in preschool children and their families in Xi'an, China. PloS one, 8(10), e77273.

Yang, J., Wang, H. P., Zhou, L., \& Xu, C. F. (2012). Effect of dietary fiber on constipation: a meta analysis. World journal of gastroenterology: WJG, 18(48), 7378.

Suwananta, I. M. ., Nesa, N. N. M. ., Karyana, I. P. G. ., \& Putra, I. G. N. S. . (2020). Toilet training and less fiber consumption as risk factors of constipation in preschool children. International Journal of Health Sciences, 4(3), 83-92. https://doi.org/10.29332/ijhs.v4n3.474 


\section{Biography of Authors}

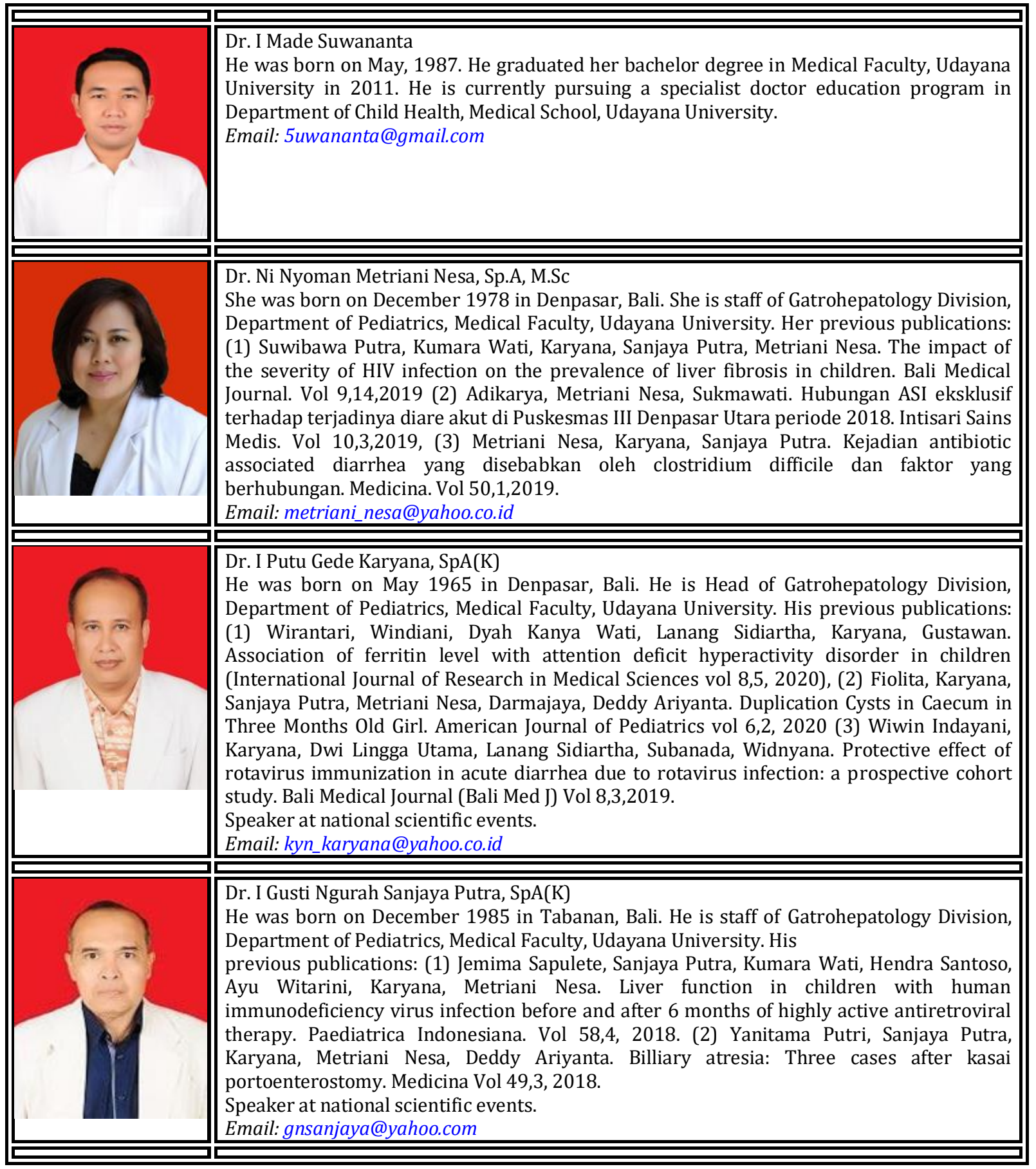

